\title{
EDUCATIONAL JOURNALISM IN UKRAINE: CURRENT STATUS AND DEVELOPMENT PROSPECTS
}

\author{
Petro Katerynych \\ Taras Shevchenko National University of Kyiv \\ vul. Yuriy Ilyenko, 36/1, Kyiv, 04119, Ukraine \\ (D) https://orcid.org/0000-0002-5967-2368 \\ katerinich1993@gmail.com
}

\begin{abstract}
The article deals with the development of the concept of "educational journalism" in Ukrainian and European journalism, defines the concept of "educational content", typology and functions of the education media outlets. The study is relevant because it is the first time in Ukrainian journalism a thorough attempt was made to study the concept of "educational journalism". The study aims to define the concept of "educational journalism" in the Ukrainian media discourse and analyze the typological and genre features (sampled by the selected online publications on educational topics). The research method is quantitative content analysis. It allows us to understand a range of problems in the field of education, which is the core focus of the analyzed media outlets, as well as the fields of education that are covered least of all. The novelty is connected with introduction of the concepts of "education media outlets", "the path of educational journalism" into Ukrainian journalism and with the development of the structure of the multimedia editorial office that is specialized in education. The complexity of work on educational content is that educational journalism per se is a specialized field of knowledge, however, preschool, secondary education, higher education, inclusive education (among others are oligophrenic education, deaf education and blindness and education), postgraduate education, andragogy are defined among the fields of education. The study presents the results of quantitative content analysis of online education media outlets "Osvita.ua", "Pedpress", "Osvitoria" and "NUS" (6623 publications of these education media outlets were analyzed), which allowed to identify themes and genres that prevail in journalistic materials on educational topics, as well as the sources of origin of these materials - the author's or borrowed ones from other resources (in particular, The Ministry of Education and Science of Ukraine). The results of the study are not only of theoretical but also practical relevance, since they can be taken into consideration during the development of curricula for the training of education journalists, conclusion of terminology and formation of recommendations for the work of education journalists..

Keywords: educational journalism; education media outlets; path of educational journalism; Pedpress; Osvita.ua; NUS; Osvitoria.
\end{abstract}

Introduction. Nowadays there is a small number of media outlets covering education in Ukraine. As a rule, the editorial offices are limited to the news on educational topics in the general news block or newscast, and do not have the separate news or analytical rubrics / programs / casts that specialize in educational content and touch upon the topical subject in the field of education. Sometimes the media outlets make a series of publications or TV stories on a specific topic - such as: "TNS" ("Television News Service") ("The recipes for Growth"1), "Ukrainian Truth" ("Agents of Change"2).

Among the specialized education media outlets in Ukraine, the following should be singled out "Osvita.ua", "Pedpress", "Osvitoria", "NUS". These are the most filled (we mean the regular content of information and analytical genres) and the most innovative (considering the multimedia component) educational mass media outlets in Ukraine. Moreover, according to the data of open traffic analysis

\footnotetext{
${ }^{1}$ https://tsn.ua/special-projects/child

2 https://life.pravda.com.ua/projects/osvita
}

portal "Similar Web" have the highest traffic in the Ukrainian segment of educational content, without taking into consideration the official sources.

Educational journalism in Ukraine is on the edge of a "crisis of professionalism" - the broad coverage of the topics of secondary and higher education, poor coverage of vocational education, science, inclusion, absence of training programs for education journalists and wide expert pool of educational topics reduces the quality of content that prepared by journalists, who write on education (Communication strategy, 2017 pp. 20-22). In the process of writing the qualification work on the research topic by the Doctor of Philosophy, the author has defined that the analyzed media outlets generally have a small number of original (author's) content, there are some significant borrowings from official sources (executive authorities) and other portals (including the foreign ones), that devalue the quality of materials on education.

\footnotetext{
${ }^{3}$ https://www.similarweb.com/website/osvita.ua
} 
A survey of field specialists (journalists writing on education, as well as other editorial staff involved in creating content on educational topics - editors, content managers) has showed that, according to respondents, Ukraine lacks analytical content on education, and the level of educational journalism is estimated at 5 out of 10 .

Purpose and objectives of the study. The study aims to define the concept of "educational journalism" in the Ukrainian media discourse and analyze the typological and genre features (by the examples of the selected online publications on educational topics).

To achieve this goal, it is necessary to solve the following tasks:

- To define the concept of "educational journalism" in journalism,

- To study the functions and typologies of education media outlets,

- To carry out a quantitative content analysis of the selected online portals that contain journalistic materials on educational topics.

The following general scientific methods are used to achieve the aim and research assignments: descriptive and comparative, as well as analysis, synthesis and generalization.

What is more, the method of quantitative content analysis was used to study the content of selected media outlets, problems of materials, genre structure and sources of content.

The object of study is educational journalism of Ukraine; the subject is selected education media outlets in terms of their typology, genre and thematic structure.

Methods of the study. The methodological basis of the study was determined by its purpose and objectives. We used a wide range of general theoretical and special scientific methods of cognition. Analysis and classification are the basic methods among the general theoretical ones.

The scientific validity and completeness of the results of the dissertation, its theoretical and methodological level are provided by the use of such methods as content analysis (to study the content of educational publications) and questionnaires.

The content of the sites "Osvita.ua", "Pedpress", "Osvitoria" and "NUS" was studied using the monitoring method and elements of the method of quantitative content analysis.

The content monitoring of the sites "Osvita.ua", "Pedpress", "Osvitoria" and "NUS", the results of which are presented in this study, was performed by the author himself.

The general set of the study consists of all textual works published on the sites "Osvita.ua", "Pedpress", "Osvitoria" and "NUS" in the analyzed sections during the study period. In order to achieve representativeness of monitoring, we were collecting data on the content of the sites "Osvita.ua", "Pedpress", "Osvitoria" and "NUS" every day during the study period (from August 30, 2019 to August 30, 2020). Accordingly, these data constitute a set sample of the study.
The correctness of our sampling procedure is ensured by the same structure of the original and analyzed sets.

In addition, during the study period we used the method of questionnaires. Expert questionnaire allowed us to identify the most important aspects of the research problem, form practical recommendations regarding the competencies of an education journalist. The main selection criterion for the expert questionnaire was the competence due to the experience of experts in the analyzed media outlets. The questionnaire of experts by sending messages to selected respondents on the social network "Facebook" or by e-mail with an invitation to take the questionnaire in a closed google-form is selective, remote, correspondent, using questions about the respondent's opinion, filter questions, closed questions and types of questions on the Likert scale and on the importance scale.

Source base of the study. From a theoretical point of view, the study of the topic of educational journalism is critically poor, unlike, let us say, environmental, sports, law or social in Ukrainian journalism. The lack of specialized research in Ukraine does not allow us to operate with a broad theoretical base, but in the process of research we were guided by the works of international experts. Among the scientific studies considered by us in the research process the works of K. Shaar (2020), G. Pérez (1998) and K. Weissner (2006), V. Rizun and V. Ivanov (2012), N. Luhmann (2002), O. Konovets (2003), M. Shash, E. Bondarenko (2015), V. Leikin (2020), S. Terepyshchyi (2016), as well as the Communication Strategy of the Ministry of Education and Science for 2017-2020 should be highlighted.

Study findings. The educational landscape is connected with the digital society and convergence of society. Education is flexibly adapted to the rapid development of communications in the era of e-journalism. The multimedia thinking, use of "smart" ideas, deep immersion into the topic and presence in the educational process are the primary tasks of a journalist who writes on educational topics.

Educational journalism is a definition used to describe the journalistic materials on socially significant educational topics of the media outlets. In European countries, educational journalism has developed since the international comparative studies of the quality of education had appeared - PISA, TIMSS. These studies represent the level of quality of national education by assessing the educational achievements of students in order to improve the quality of teaching and organization of education systems. These studies always provoke a considerable journalists' reaction, as the studies provide the assess of success of the education system compared to other countries. PISA, for example, covers 80 countries, which make up more than $80 \%$ of the world economy ${ }^{4}$.

${ }^{4}$ http://pisa.testportal.gov.ua 
According to the German researcher N. Luhmann, education is the most important functional system of modern differentiated society which is responsible for the transfer of knowledge and values (Luhmann, 2002). Educational journalism functions as an integration system that serves as a body for monitoring, verification and control and contributes to the development of the knowledge economy.

The task of educational journalism, according to $\mathrm{K}$. Wiesner, is, among other things, to explain the complex relationships between national and international education systems and ratings (PISA, TIMSS, PIRLS, Starting Strong, TALIS, DESI, LAU, etc.) (Wiesner, 2006, pp. 32-42).

A child-oriented approach, the ability to build a dialogue with education actors - politicians, teachers, parents, students, ability to provide the unconventional information on educational topics, different formats of content formation, as well as use of multimedia tools are the key requirements for a modern journalist, who specializes in education. For another thing, the broad involvement of education experts and leaders of the fields requires the journalist to build his own "expert base" on various educational issues while creating the content.

The immanent factor of educational journalism is child-centered, human communication, however the ability to present information on educational topics in a non-standard way, build a dialogue between areas of interest avoiding formal words and using various message formats and tools have been the challenging tasks for managers for a long time. Therefore, the communication moves to the stage of "real stories", through which information is presented more accessible and creates interaction between the communicator and the recipient.

Russian researcher V. Leikin notes: "media outlets lack only educational content, it is necessary to cover the topic of education" (Leikin, 2020, pp. 567-575). According to the researcher, the importance of covering the topic of education may exceed the importance of the actual educational content. "The development of educational sphere also depends on how the media outlets provide information about it. If the media outlets do not cover the educational sphere enough and do not focus public attention on the problems of modern education, then the process of development of this sphere may be erroneous or slow down significantly. Nowadays, however, the educational sphere is mostly covered by people who are "savvy" in this matter. The authors of articles, creators of radio or television programs of educational orientation are journalists who understand the pedagogical subject, and often the teachers themselves are the founders of educational media", says V. Leikin (Leikin, 2020, pp. 567-575). In Ukraine, there is a visual confirmation of this thesis - Honored Worker of Education of Ukraine, public figure and entrepreneur Zoya Lytvyn, who is the founder of the elite Novopechersk school, as well as a chairman of the public association "Osvitoria" (analyzed in the study), which includes the same name resource with educational content. Moreover, Zoya Lytvyn is the founder of the national award for teachersinnovators "Global Teacher Prize Ukraine".

A deep understanding of the concept of "educational journalism" is reflected in the research of a German scientist K. Schaar. The researcher writes that educational journalism contributes to a deeper understanding of scientific discoveries, simplifies information about new trends, as well as classifies them socially and politically. The scientist mentions the main topics that a modern education journalist should be interested in. These include the demographic change in society, age-related interactions, health and education, innovative teaching methods, and qualitative and quantitative social and research in education (Schaar, 2020).

The German experience in the field of educational journalism is the most complete of the international practices we have analyzed (American and Spanish are less complex and developed).

Serhiy Terepyshchyi in his monograph "Modern educational landscapes" writes that "the scale of the information and communication boom is only a superficial description of the changes that happen with humanity at the moment. Against the background of social change, the personality itself is causally transformed: the image of a modern intelligent creature can be conditionally called "informational human" "homo informationes" (Terepyshchyi, 2016, p. 132). The author shares the opinion of T. Fitzgerald, H. Gunter, and J. White on the vision of the dependence of the educational landscape of the information society on other social and economic institutions (Fitzgerald et al., 2012).

M. Shash and E. Bondarenko note that the current problems of interaction between education and the media outlets are a field of interdisciplinary research carried out by philosophers, psychologists, teachers, journalists, sociologists and highlight the phenomenon of "parallel school" - the impact of media outlets information on students, which result the distorted picture of the world. The authors offer to combat the phenomenon of "parallel school" as a negative socio-cultural and educational phenomenon (Shash \& Bondarenko, 2015).

According to O. Konovets, the communicative field of education in Ukraine is underdeveloped, there is a need to create media outlets aimed at informing about innovations in education and science spheres. The scholar emphasizes that "the educational and pedagogical function realized by modern media outlets plays a leading role in the democratization of Ukrainian education, formation of civil society as a whole" (Konovets, 2003).

Considering the definition of educational journalism and its functions, we should mention the "journalism of interaction". An education journalist interacts with a group of people of different ages, that represent various educational fields, which, in turn, have a unique structure. It is important to understand that the 
one-sided interaction "education journalist — parents" or "education journalist — students" will be incomplete and will not allow to immerse deeply into the topic. To reveal the diverse nature of the educational problem, it is necessary to interact with different groups in this hierarchy (Fig. 1).

Figure 1. The interaction in the field of educational journalism. Our own development.

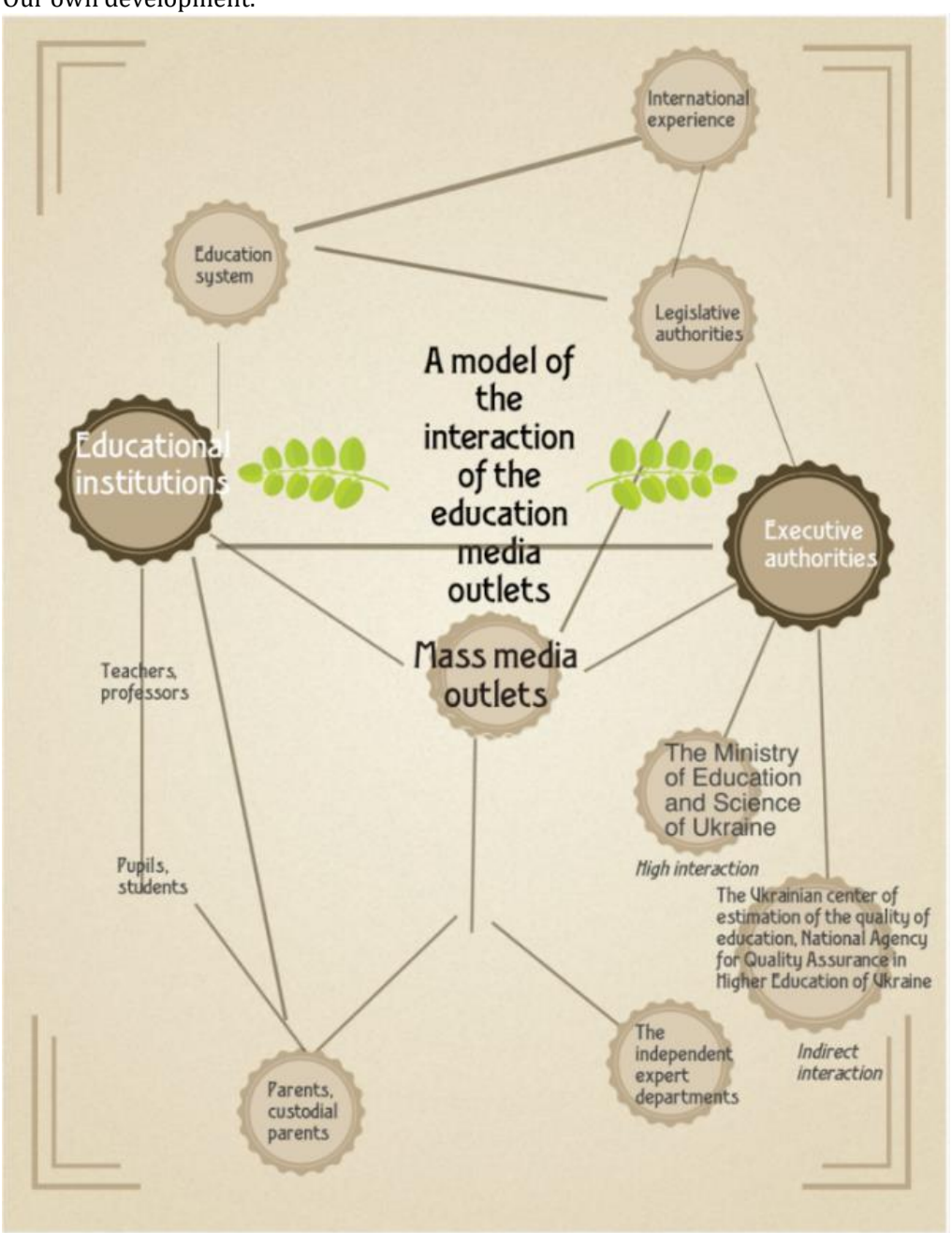
the most.

materials in the national media outlets, lack of advertising and communication campaigns on education, vocational education and the sciences suffer

"Journalists of academic background should bring the complex educational topics into limelight in a way that is quite understandable for non-specialists" is stated on the website of the German award for journalists who write on educational topics $^{6}$. It is possible to develop and create the specialized platforms where you can find experts on various educational issues, communicate with them, invite them to broadcast or ask for comment. An example is the German portal "Agency for Educational Journalism". In Ukraine, there is a website "Educational Policy: a portal for public experts", however it is rarely filled?.

The conceptual basis of educational journalism is not developed by Ukrainian researchers, and there is a lack of its processing at the international level too.

First of all, it is necessary to define the concept of "education media outlet". In our opinion, education media outlet (identical to educational media) is the media outlet that specializes in the collection, processing and distribution of news and analytical content of educational nature with a narrow or broad background, with the use of multimedia content production and has the appropriate infrastructure and staff.

According to Professor of Educational Journalism at the University of Seville G. Pérez, "educational journalism is a systematic, socially oriented understanding of relevant information in educational processes, which we call "educational society" or "lifelong learning" (Pérez, 1998, pp. 172-183).

In our opinion, it is necessary to distin-

Thus, educational media outlets interact with educational systems not directly, but through the authorities or educational institutions.

Kevin Carey, the director of educational policy for the New America Foundation, in the article by American journalist Libby Nelson "Why Journalists Hate to Write About Education," states that the majority of journalists avoid the opportunity to write about education because the subject is complex and lacks direct drama and conflict, "as it happens when covering politics, foreign affairs or business." Carey says: "There are no clear heroes or villains, the real problem - education - is difficult to portray" (Nelson, 2014).

Looksmi's media monitoring data ${ }^{5}$ on the state of the Ukrainian education system in 2016 shows that education is less covered than other current government topics. A critical shortage of analytical

${ }^{5}$ https://looqme.io/uk guish the journalistic materials on educational topics that are prepared by professional journalists and the materials that are prepared for educational or didactic purposes, which are intended to be used in highly specialized publications. For such materials, we recommend to use the definition of "pedagogical material" or "pedagogical journalism" — that is the material of popular-science or scientific nature created by a specialist (teacher, educator, mentor).
${ }^{6}$ https://www.telekom-stiftung.de/projekte/medienpreisbildungsjournalismus

${ }^{7}$ http://education-ua.org/ua 
V. Rizun and V. Ivanov pay attention to the problems of journalist training in the study "Education in the field of media". The researchers write that "the licensed amount of journalism training is about 3,800 , i.e. theoretically this is the maximum number of the journalists that can be produced" (Rizun \& Ivanov, 2012, pp. 44-48). This number (3,800 students) includes no one who would be trained as a specialist in the media market of education media outlets. In Ukraine, there are no textbooks or practical manuals for journalists who specialize in education, besides that, there are no works that cover the ethical nature of news in the field of education, as in the United States - Education writers association (EWA, the association that unite the education journalists ${ }^{8}$. EWA has also published a guide for journalists, where the specialists provide some recommendations on how to write on topics that are social stimuli the education depended on race, sex, religion, sexual orientation and gender identity.

Educational journalism, according to G. Pérez, cannot simply be added to other disciplines in the usual academic framework, because it covers them all without exception (Pérez, 1998).

The analysis of educational effectiveness for an education journalist is of great importance - the success of reforms, work of government or educational institutions. We define the educational efficiency as a set of components and criteria by which we can determine the current state of development of the educational filed. There are key categories of educational fields that are relevant for an education journalist today. They are grouped by fields of education. In this article, we do not focus on categories, however you will have a chance to get acquainted with them in the author's dissertation research.

The educational range of problems should be divided into global (concerning the field of education in general) and local, which will be unique for each educational field. Education in general should be as well divided into global (global trends and processes in the field of education) and local (national educational processes).

The informatization of education, visualization of the educational space, innovation of the educational landscape is a challenge for a journalist who covers the educational topics. An education journalist must

${ }^{8}$ https://www.ewa.org use a wide range of multimedia tools in order to work with content. Multimedia editorial office of world educational media is hierarchically divided into areas of responsibility - for creation content, its distribution, cooperation with advertisers, contact with readers, creation of other types of content, namely the publications or special projects, work on information and computing support of the journalist. As an example, we propose to review the structure of the multimedia editorial office that is created for the needs of the newest market (Fig. 2).

Figure 2. An exemplary structure of the multimedia editorial offices, that are specialized in educational topics. Our own development.

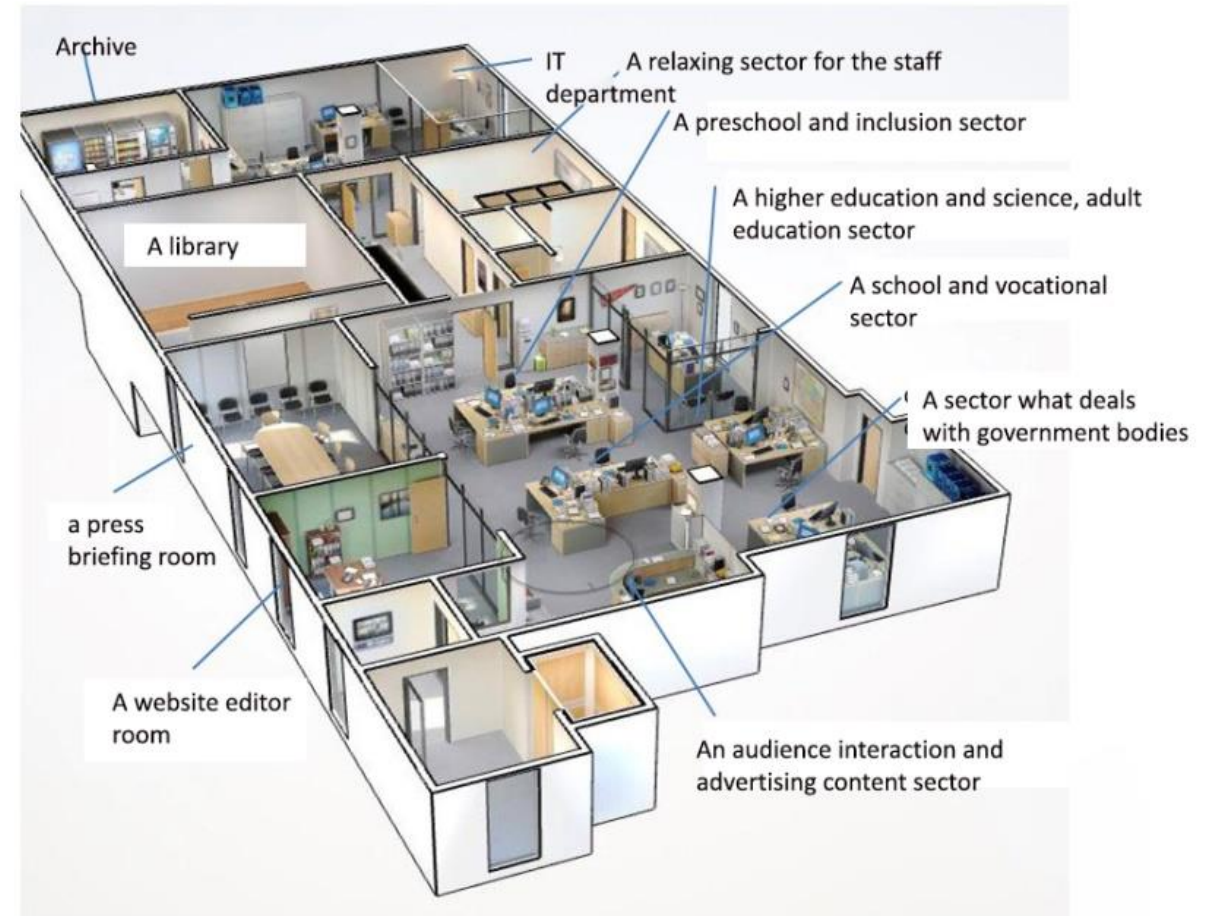

Shifting from the content of the concepts "educational journalism", "multimedia editorial office on educational topics", it should be noted that there are many different models that describe the functions of journalism - these are the "classic" models of D. McQuayl, approaches of W. Sibert, T. Peterson and W. Schramm, work of K. Christian "Standards of media theory: journalism in democratic societies" (Christians et al., 2009, p. 275), (McQuail, 1987), (Siebert et al., 1956).

Since educational journalism is a separate field, we recommend to identify the following functions of education media outlets, based on the analysis conducted in our study:

- Informing (reports on events and phenomena in the field of education),

- Cognitive (open the reader's mind),

- Stratifying (the distinction of different educational areas and education actors depending on the functions and role),

- Critical (impartial study and information on the activities of authorities in the field of education, research and educational institutions), 
- Scientific and innovative (the creation of an idea of innovative development of society and scientific progress in Ukraine and abroad),

- Evaluative and stimulating (as an assessment of the state of the system and the aspiration for progress),

- Mythological (as the formation of public myth about national education and the role of teachers; refutation of these myths),

- Entertaining (informational and entertaining content that is thematically related to the topic of education).

If we talk about the typology of the media outlets, in a broad sense, it summarizes the most characteristic features and peculiarities of the media outlets (VUE, 2020).

We propose to divide online media outlets covering education in the following way:

- Synthetic publications (the combination of educational content and pedagogical component) "Osvita.ua", "Pedpress".

- Trivial - the standard information resources of non-compact structure, that are devoid of innovative component; information-analytical component is present, but there is no visualization and visibility of data) - "Educational policy. A portal of public experts", "Ukrainian pedagogy".

- Innovative - the prevalence of informational content, presented in a simplified manner, is visualized using multimedia tools and smart technologies ("Osvitoria", "NUS").

Having regard to the aim of the study, it is important for our research to carry out a content analysis of selected education media outlets. The object of analysis was the content of education media outlets, the subject of the study was the content of the websites, namely "Osvita.ua", "Pedpress", "Osvitoria" and "NUS" for the period from August 30, 2019 to August 30, 2020.

The content of the websites "Osvita.ua", "Pedpress", "Osvitoria" and "NUS" was researched using the monitoring method and elements of the method of quantitative content analysis.

The general set of the study consists of all textual works published on the websites "Osvita.ua", "Pedpress", "Osvitoria" and "NUS" in the analyzed sections during the study period. The selective set of the study is the content published on the websites "Osvita.ua", "Pedpress", "Osvitoria" and "NUS" during the study period: from August 30, 2019 to August 30, 2020.

For analysis, we have chosen the main rubrics (for representativeness -5 rubrics of each portal) of the analyzed websites "Osvita.ua" ("News", "Secondary Education", "EIT (External independent evaluation)", "Higher Education", "Education Abroad"); "Pedpress" ("Preschool education", "Secondary education", "Vocational education", "Higher education", "EIT"), "NUS" ("News", "Articles", "There are some questions", "View", "Inclusion"); "Osvitoria” ("News", “Magazine", "Poster", "Blogs", “Just do it"), which allows us to talk about the coverage of content of both analytical and information-entertaining type.

The genre palette of the textual content of the researched rubrics consists of works of information genres (notes, reports, interviews) and analytical genres (articles).

With the help of units of analysis, we have identified all the text gaps that are published on the sites "Osvita.ua", "Pedpress", "Osvitoria" and "NUS" during the study period in the relevant rubrics.

Our content analysis allows us to say that among the analyzed content of four online offices of educational specialization (6623 publications) by genre structure, notes and articles prevail, but there is a lack of reports and interviews. There is a problem with unique content. Most of the materials of "Pedpress", as well as a significant part of "Osvita.ua" are the borrowed or additional material of official websites of the Ministry of Education and Science of Ukraine, Ukrainian Center for Education Quality Assessment and others.

The topic of "science" is poorly covered - the materials on the "brain drain", material support of scientists, development of science and innovation parks, international experience and innovation and technology transfer - are isolated.

Among the materials of the analyzed media outlets related to preschool, the topics of distance education, organization of education in primary schools during the quarantine period and problem of establishing the child's personal space prevail. The topic of inclusion in primary schools is poorly covered. The topics of distance learning, the new Ukrainian school, External independent evaluation and teachers' salaries prevail among the materials related to primary and secondary education, and as for mental retardation, deaf and blindness topics, these topics are poorly covered.

The amount of materials about the field of vocational education does not exceed $3.5 \%$ of the total number of analyzed materials in each media outlet. Among the materials on the field of higher education, the analyzed media outlets focus on the issues of the entrance examinations and state order, the increased attention to the Ukrainian educational institutions entrance of the residents of Crimea and Donbass region. With regard to science and innovation, the analyzed media outlets cover mainly the foreign experience; a number of analytical materials on the processes taking place in Ukrainian science is critically low (less than $0.5 \%$ ). The topic of adult education is covered at the level of $0.3 \%$ of the total amount of materials, although the postulates of "lifelong learning" were found in $2.65 \%$ of the materials. The amount of materials devoted to bullying is relatively high (1.5\%).

Thus, in our research, we have studied the development of the concept of "educational journalism" in Ukrainian and international journalism, defined the functions and types of education media outlets. 
Due to the content analysis of the selected education media outlets, we have found out the topics that prevail in the analyzed content, determined that the topics of vocational education, science and innovation, inclusion are poorly covered.

In addition, the majority of the materials of "Pedpress", as well as a significant part of "Osvita.ua" are borrowed from other sources; as for "NUS" and "Osvitoria", these websites are full of a large amount of author's analytical content.

Considering the statements above, we deem it advisable to make Ukrainian media outlets interested in the problems of science and education of children with special educational needs, enlarge the number of materials on educational practices in vocational schools and the number of author's content, particularly the reports from educational institutions and interviews of successful managers and youth.

Thirteen respondents answered the questions posed in our survey, which we sent to journalists and editors specializing in the creation of educational content. There were journalists, editors, educational experts ( 9 women, 4 men) among them. According to the criterion of "obtained education" seven respondents are journalists, four ones have a pedagogical education, one person has a law education, and one more respondent obtained Ukrainian philology education. According to the job criterion, four respondents work in "Osvitoria", other two ones work in "Osvita.ua", two - in "Vseosvita", two - in the newspaper "Modern Education of Ukraine", and by one - in "NUS", one - in the center of innovative education "Pro.Svit" and one - in "Mirrors of the Week" (analytical publication that does not specialize in education). Ten respondents are journalists, two others are editors and one person is a content manager. Nine respondents indicated work experience of more than two years, three of them - one or two years and one respondent indicated less than a year work experience. Eight respondents consider themselves to be the specialized educational journalists, and five indicate that they specialize in a wide range of topics. The level of educational journalism in Ukraine on a scale from " 1 " to " 10 " respondents rated an average of 5 points (the lowest score -3 , a representative of "Osvita.ua", the highest -8 , a representative of the "New Ukrainian School"). The importance of journalist education to work as an education journalist on a scale from " 1 " to " 10 " respondents rated an average of 5 points (the lowest score " 1 ", the highest - " 10 ").

With the statement that in Ukraine there is a lack of author's analytical content on education topics, on a scale from 1 (sufficient) to 10 (insufficient) respondents on average agreed on 8 points ( 4 answers " 10 ", 3 answers " 9 ", 4 answers " 8 ", 1 answer " 7 " and 1 answer " 3 "). Among the skills that respondents consider important for the work of an education journalist are the selection of information based on the reliability of sources, knowledge of educational laws, understanding the needs of the audience and study- ing the interests of parents and children. The majority of respondents chose searching for news and checking sources, advanced search for information on the Internet, interviewing techniques, interpretation of statistics and graphics, generating ideas and meanings of the database of experts and stakeholders, literacy, self-editing, digital comprehension environment (analysis of audience expectations, study of competitors) when answering the question "Which of the following skills do you use in journalism?"

Conclusions. We analyzed the theoretical developments of Ukrainian and foreign experts regarding the educational journalism definition, as well as the skills of education journalist. Due to the content analysis of four specialized Internet resources, which contain journalistic content on education, we succeeded in outlining the key problems of educational journalism in Ukraine. These problems include a low percentage of author's materials, a small amount of material relating to the fields of science and vocational education, "brain drain". By conducting the expert questionnaire, we outlined the skills that are important for an education journalist. We also determined that experts note the low amount of analytical materials on education in Ukraine, and generally a small amount of author's analytical content. The results of the study can be used to develop the curriculum for the training of education journalists, form the recommendations for the work of education journalists, create and develop the online platforms on educational topics.

\section{References (translated and transliterated)}

Christians, C. G., Glasser, T. L., ... McQuail, D. (2009). Normative theories of the media: journalism in democratic societies. University of Illinois Press.

Fitzgerald, T., Gunter, H., \& White, J. (Eds.) (2012). Hard labour? Academic work and the changing landscape of higher education, Vol. 7. Emerald Group Publishing. https://doi.org/10.1108/ S1479-3628(2012)7

Komunikatsiyna stratehiya MON 2017-2020 rr. [Communication strategy of Ministry of Education and Science of Ukraine 2017-2020]. (2017). https://mon.gov.ua/storage/app/media/ komunikaczijna-strategiya-mon-2017-2020.pdf

Konovets, O. (2003). Aktualni pytannia masovo-informatsiinoi pidtrymky ukrainskoi osvity. [Current issues of mass communication support for Ukrainian education]. Naukovi zapysky instytutu zhurnalistyky, 11, 101-106.

Leikin, V. (2020). Obrazovatel'naja zhurnalistika: problemy i perspektivy. [Educational journalism: problems and perspectives] Global \& regional research, 2, 567-575.

Luhmann, N. (2002). Das Erziehungssystem der Gesellschaft. Frankfurt a. M.: Suhrkamp.

McQuail, D. (1987). Mass Communication Theory: An Introduction. SAGE Publications.

Nelson, L. (2014, December 22). Why journalists hate to write about education. Vox. https://www.vox.com/2014/12/22/ 7435883/education-journalism-kevin-carey

Pérez., G. (1998). El periodismo educativo: objetivos. Revista Latina de Comunicacion Social, 15, 172-183. https://doi.org/10.12795/Ambitos.1998.i01.08

Rizun, V., \& Ivanov, V. (2013). Osvita u sferi media [Education in the field of media]. In V. Ivanov, O. Volosheniuk, \& A. Kulakova (Eds.). Ukrayins'kyy medialandshaft - 2012 (pp. 44-48). Kyiv.

Schaar, K. (2020). Bildungsjournalismus. http://bildungsjournalismus.de/ 
Shash, M., \& Bondarenko, E. (2015). Rol' SMI v uchebnovospitatel'nom processe... [The role of the media in the educational process]. Mediaobrazovanie, 1, pp. 50-64.

Siebert, F. S., Peterson, T., \& Schramm, W. (1956). Four theories of the press: The authoritarian, libertarian, social responsibility, and Soviet communist concepts of what the press should be and do. University of Illinois Press.

Terepyshchyi, S. (2016). Suchasni osvitni landshafty [Modern educational landscapes]. Kyiv: Feniks.
VUE [The Great Ukrainian Encyclopedia]. (2020). Typolohiya ZMI [Typology of mass media]. https://vue.gov.ua

Wiesner, Ch., \& Peherstorfer, M. (2006). Bildungsjournalismus als Herausforderung. PISA-Berichterstattung 2004. In: Journalismus in Österreich (S. 32-42). Salzburg: Abteilung Journalistik, Fachbereich Kommunikationswissenschaft, Universität Salzburg.

\title{
ОСВІТНЯ ЖУРНАЛІСТИКА В УКРАЇНІ: СУЧАСНИЙ СТАН I ПЕРСПЕКТИВИ РОЗВИТКУ
}

\author{
Петро Катеринич \\ Київський національний університет імені Тараса Шевченка, Україна
}

\begin{abstract}
У статті вивчено розробленість поняття «освітньої журналістики» в українському та європейському журналістикознавстві, визначено поняття «контенту освітньої тематики», типологію та функції ЗМІ на освітню тематику. Дослідження є актуальним, оскільки вперше в українському журналістикознавстві здійснено грунтовну спробу дослідити поняття «освітньої журналістики». Мета дослідження - визначити поняття «освітньої журналістики» в українському медіадискурсі та проаналізувати типологічні й жанрові особливості (на прикладі обраних інтернет-видань освітньої тематики). Методом дослідження обрано кількісний контент-аналіз, оскільки він дає змогу зрозуміти проблематику в освітній сфері, на якій аналізовані 3МІ акцентують найвищу увагу, а також галузі освіти, що висвітлюються найменше. Новизна роботи полягає у введенні до українського журналістикознавства поняття «ЗМІ освітньої тематики», «траєкторії освітньої журналістики», розробці структури мультимедійної редакції освітнього ЗМІ. Складність роботи з контентом освітньої тематики полягає в тому, що освітня журналістика per se $\epsilon$ спеціалізованою галуззю знань, однак серед галузей освіти виділяють дошкілля, середню освіту, вищу, інклюзивну (між іншим, олігофрено-, сурдо- і тифлопедагогіки), післядипломну, андрагогіку. У дослідженні наведено результати кількісного контент-аналізу інтернет-ЗМІ освітньої тематики «Освіта.иа», «Педпреса», «Освіторія» та «НУШ» (загалом проаналізовано 6623 публікації в цих 3МI), що сприяло визначенню тем і жанрів, які превалюють у журналістських матеріалах на освітню тематику, а також джерел походження цих матеріалів авторських чи запозичених з інших ресурсів (зокрема МОНУ). Результати дослідження мають не лише теоретичне, але й практичне значення, оскільки можуть бути враховані в ході розробки навчальних програм для підготовки освітніх журналістів, укладання термінологічної бази та формування рекомендацій для роботи освітнього журналіста.

Ключові слова: освітня журналістика; 3МІ освітньої тематики; траєкторії освітньої журналістики; Педпреса; Освіта.иа; НУШ; Освіторія.
\end{abstract}

